\title{
The Civic Political Culture: Social Barriers and Educational Resource of Modernization
}

\author{
Irina Dolinina
}

\begin{abstract}
The article analyzes and characterizes the content, empirics of scientific research and the practice of implementing the methodological foundations of the political culture of students, as the basis for the formation of a civic national identity and ultimately the formation of the unity of the Russian nation.

The relevance of the article is due to the aggravation of the socio-political situation in the Russian Federation in recent years, which is associated with an increase in the need for peaceful resolution of conflicts, the need for preparation for civic participation in the life of society and the state, and the insufficient level of political culture of all participants in the events. It is shown that at present, the educational system of Russia contains a large-scale error of violating ideological continuity between basic general / secondary / education and higher professional education. In particular, the Federal State Standard for Basic General Education dated 2010.12.10 indicates the orientation of education in the Russian Federation "to ensure the formation of the Russian civic identity of students", but the Federal State Educational Standard on humanitarian directions of training do not have the ideological principles contained in the standards of general and secondary education and including in the Constitution of the Russian Federation.

The research problem is connected with the search for methodological foundations for the implementation of the requirements of educational standards and the continuity in higher education of the formation of the Russian civic identity of students, their testing and dissemination of the progressive experience available in our country.
\end{abstract}

Keywords: Political culture of students, formation, civic identity.

\section{INTRODUCTION} separated from the humanistic civic essence. Not infrequently, political events cast doubt on many of our assumptions about how the social and political world is organized.

Most importantly, this work examines how civic culture exists not only within the framework of a separate national history and traditions, but also beyond national, linguistic and cultural boundaries through the development of formal and non-formal education. It is based on the issue of trust not only in the politicians themselves, but also in the political process as a whole and the possibilities of civic participation. The lack of influence of civic participation of the population and

Revised Manuscript Received on February 12, 2020.

* Correspondence Author

Irina Dolinina* Department of Life Safety, Perm National Research Polytechnic University, Perm, Russia. Email: irina_edu@mail.ru

(C) The Authors. Published by Blue Eyes Intelligence Engineering and Sciences Publication (BEIESP). This is an open access article under the CC BY-NC-ND license (http://creativecommons.org/licenses/by-nc-nd/4.0/)
In our turbulent days, we are observing, humanity is being

youth, a legitimate way of determining their political status provokes the extremist part of society on unconstitutional actions, which is a direct threat to Russia's state security.

As the political practice of Russia shows, the transformation of the political system of the state can constructively be carried out only as a revolution from above, and not as a "Russian rebellion, meaningless and merciless."

The leading idea of the presented research is to solve one of the most important tasks of the development of our society at the present stage in the formation of a civic political culture in conditions when the older generation is not able to pass on such experience due to the lack of such experience in Soviet society, and the existing educational system does not provide for it the younger generation, or provides with insufficient methodological support.

The methodological basis of the study was the principle of historicism, which helped to clarify the relationship of thinkers and public figures to political culture in society and education in various historical periods; the principle of systemic that allowed us to implement a research methodology, to consider the educational space of the formation of a political culture as the interconnection of elements in the totality of relations and relations between them based on integrity, hierarchy, multiplicity; the principle of value orientation, which assumes that the dominance of one political ideology is not assumed and which allowed the formation of a value system for students, including the value of human rights, the inviolability of private property, and pluralism of opinions; the principle of the interconnection of training and upbringing has made it possible to develop educational and upbringing components of preparation for political participation. The educational tasks of the formation of a political culture are implemented as a comprehensive impact on a person with the aim of influencing the worldview, value attitudes, personal qualities of a sovereign and responsible citizen.

\section{PRESEARCH BASE}

The study began in 1994 and continues to the present day.

At different stages, the study was supported by the Council of Federations of the Russian Federation, the Legislative Assembly of the Perm Territory, universities and journalists.

The study covered more than three thousand people: high school students, university students, members of public organizations (Discussion Club "I am a Citizen", Interregional Association "For Civic Education", "Scientific and Methodological Center for the Development of Political Culture). Investigations were carried out and three candidates and one doctoral were defended. 
The effectiveness of the methodology of the formation of a civic political culture is achieved through the interaction of modern humanities, the creation of a focused educational space in classroom and social science work, as evidenced by the wide testing of theoretical principles in educational and public institutions. The study can be the starting point for positive changes in Russian education and society as a whole.

\section{STRUCTURE OF POLITICAL CULTURE}

The term "political culture" acquired a categorical status in Western literature in 1956 in the works of American political scientists G. Almond and S. Verba. They believed that political culture is a special type of orientation on political action, reflecting the specifics of each political system. Political culture is a part of the general culture, closely connected with a specific political system.

G. Almond and S. Verba wrote: "When we talk about the political culture of society, we mean a political system, internalized in the knowledge, feelings and appreciation of its members" [1].

Considering political culture as a socio cultural phenomenon, foreign authors have different approaches to the interpretation of this concept.

Researchers identify "three main approaches. The objectivist approach (R. Carr, M. Bernstein, R. Tucker and others). Political culture from the perspective of an objectivist approach is a culture of behavior in politics.The subjectivist approach - M. Foucault, J. Habermas and others. In their understanding, political culture is the imposition of political meanings and orientation on an individual. This agreement is about the goals and meanings of the policies pursued. The constructionist approach (G. Almond, S. Verba, S. Lipset, S. White, R. Lane, A. Wildavsky, R. Englehart and others). This is a value vision of political culture, the essence of which is that it is political values that motivate human activity in the political sphere, direct and justify the social actions of socio-political actors"[2].

Political culture is a system of historically established, relatively stable, embodying the experiences of previous generations of people attitudes, orientations and patterns of behavior (functioning), manifested in the direct activities of the subjects of the political process, fixing the principles of their relationship to this process as a whole, its main elements and thereby providing reproduction of the political life of society[3, 4].

The integration of the main components of a political culture - political experience, consciousness and behavior — is a complex phenomenon.

The focus on the formation of a civic political culture is oriented towards civic participation [5]. The principle of civic participation implies that the interests of all sectors of society should be represented in the political process and taken into account when making decision. It is about the inclusion of citizens in the discussion and development of political, socio-economic, cultural programs and projects, about the impact on decision-making and monitoring of their implementation, about self-government at the local level.

There is a strong relationship between political culture and political behavior. Firstly, political behavior can be explained only taking into account the phenomenon of political culture. Secondly, political culture is realized only through political behavior. And finally, thirdly, forms of political behavior can be used as indicators of political culture to characterize its content and structure. Political culture, being a dynamic entity, can be subject to transformation, as a result of which there is a change in the basic values that affect civic participation. Researchers note the historical features of the political culture of Russia: the authoritarian nature of power, the political dominance of the bureaucracy, paternalism, clientelism in the relationship of the population to power, weak degree of structured society, sacralization of power, personification of political relations, commitment to charismatic leaders.

In recent years, the sustainable tendency of stability in the political and economic system of Russia is gradually changing to dynamics in connection with many events. Today, modern Russia is undergoing significant changes that affect the political culture of the population: a qualitative transformation of the political regime; unpopular economic reforms; reconstruction of an outdated political system.

According to analysts "In the views of the Russians there are, as it were, two versions of democracy: formally normative, perceived by society as a set of norms, procedures and institutions (multi-party system, elective government, civil liberties, etc.), instrumental-active, when democracy and its institutions are evaluated by society as a mechanism for the realization of the common good " [6].

The study recorded the uncertainty of Russia's transition to democratization, which shows the uncertain state of political culture. Of interest are the opinions of Russians about the prospects for the development of a country in which a slight predominance of positive moods in relation to democratic modernization has not been revealed.

However, according to V.D. Zorkin, Chairman of the Constitutional Court of the Russian Federation, "In the group of respondents aged 18 to 30, the share of supporters of a democratic alternative for Russia exceeds $60 \%$ " [7, 8].

This information makes it possible to conclude that most Russians support democratic modernization, on the other hand, the opinions of young people also show the prospects of various types of education related to civic political culture, civic participation and electoral activity.

In recent years, we have been witnessing an attempt by the state to create an ideological framework in the consciousness of citizens, a kind of irrational revanchism.

Significant factor that limits freedom of the state in matters of searching and developing ideological principles and bases in Russia, but does not limit society in resolving this issue, these are the norms of the Constitution of the Russian Federation, which recognizes ideological diversity:

it is not allowed to establish any ideology as state or mandatory; political diversity, multi-party system is recognized; creation and activity of public associations is prohibited, unions whose goals or actions are aimed at forcibly changing the foundations of the constitutional system and violating the integrity of the Russian Federation, undermining the security of the state, creating armed groups, inciting social, racial, national and religious hatred [9].

Note that ideology is a system of values, ideals, a set of conscious ways and methods of achieving goals and achieving truths.

Published By:

Blue Eyes Intelligence Engineering 
The ideology of society is determined by the principles of the Constitution.

The second chapter of the Constitution of the Russian Federation regulates the rights and freedoms of man and citizen, as a normative standard and a type of relationship between a person and the state: personal, political, socio-economic, cultural.

Monitoring of students' opinions on human rights has revealed the priority of rights related to social guarantees (the right to housing, labor, medical care, education). Respondents do not attach any importance to freedom of speech as values.

Awareness of the need for social guarantees has increased even more due to the negative attitude towards pension reform. Justice, sovereignty and democracy - such preferences of Russians were revealed by the research center of the Institute of Sociology of the Russian Academy of Sciences. The main value remains social justice, the value of which has grown from 47 to $59 \%$.

Orientation to social rights in the minds of students is often accompanied by absenteeism, a conscious deviation from participation in the political life of the country, which indicates a crisis of the legitimacy of the political system, its norms and values. This phenomenon is part of the general crisis of mass consciousness, the alienation of the population from power, and distrust of its power structures.

"Deviations may occur in the socialization of youth, which impede the reproduction by young people of the value-normative basis of the civic identity of this society" [10]. At the same time, "there has been a tendency toward an increase in the orientation of the civic identity of young people towards curtailing the unregulated space of freedom and increased risk and expanding the space of guarantees in all fields of identification: socio-cultural, socio-economic, and political" [11, 12].

\section{DEVELOPMENT OF METHODOLOGY}

Long-term studies of civic political culture are developed in studies of graduate students at various educational levels and conditions.

The pedagogical potential of network interaction in the aggregate of possibilities has been revealed (expanding the freedom of action of the subjects of network interaction, modeling the relationships the subjects of interaction; designing the multifaceted content of various forms of joint activity to enhance the "civic initiative" of students; dissemination of experience in the formation of civic qualities of students), and resources (communication, methodological, educational) constituting a meaningful basis for the formation of civil competence of students [13].

Subsequently, the ideas of the effectiveness of network interaction were enshrined in the Federal Law "About Education in the Russian Federation" N 273-FL: "The network form for the implementation of educational programs (hereinafter referred to as the network form) provides the opportunity for students to master the educational program using the resources of several organizations engaged in educational activities, including foreign ones, and also, if necessary, using the resources of other organizations. In the implementation of educational programs using the network forms along with organizations engaged in educational activities, scientific organizations, medical organizations, organizational culture, physical culture and sports and other organizations with the resources necessary to carry out teaching, training and manufacturing practices and the implementation of other types of learning activities provided appropriate educational program "[14] .

This norm promotes the development of civic society and civic culture and, accordingly, civic competence of students.

It is proved that the "civic competence of students" is an integrative personality profile determined by willingness and ability to take an active part in social and political life on the basis of acquired civic knowledge, expressed civic position, existing civic experience, in contrast to existing studies considering the study definition as: possession competencies of citizenship (I.A. Zimnyaya); a set of qualifying prerequisites for the exercise of rights and the fulfillment of duties that are determined by citizenship status (H. Münkler); synthesis of motivational-value, cognitive, activity and personality components (E.V. Mitina). [13].

Undoubtedly, an obligatory part of civic culture is not only knowledge of democratic laws, but also the legal culture of students - respectful attitude of students to law and the rule of law, mastery of abilities and lawful behavior, allowing socially approved actions in the main areas of public life (economic, social, political and spiritual) [15].

The content of the concept of "legal education" is specified, considered as information and educational activities carried out with the involvement of educational and public resources, ensuring the accumulation of legal knowledge of students, a stable position in relation to law and legality as a social value, mastery of the ability to apply laws in real practice, in contrast to existing studies that are close in meaning definitions: dissemination of legal knowledge in the form of education (E.A. Pevtsova); preventive direction of the professional activity of a social worker (A.A. Polkhanov); purposeful activities of state organizations, public and religious associations, labor collectives and individual citizens to transfer legal experience (M.V. Snegireva) [15].

The possibilities of legal education of vocational education institutions for the formation of students' legal culture are revealed: free access and use of information and legal systems and visual and demonstration materials in order to obtain legal information, variety of educational events, and information support in the field of legal action [15].

The statistical processing of the data obtained during the experimental work and the positive dynamics for all indicators of these scientific ideas gave reason to conclude that the goal of the study was achieved, the hypothesis is proved, the tasks are solved.

\section{RESULT AND DISCUSSION}

The content of education in the field of civic political culture caused by the needs of society for sustainable ravity $[16,17]$.

Scientists, teachers, and civic leaders should consider the following points:

Published By:

Blue Eyes Intelligence Engineering

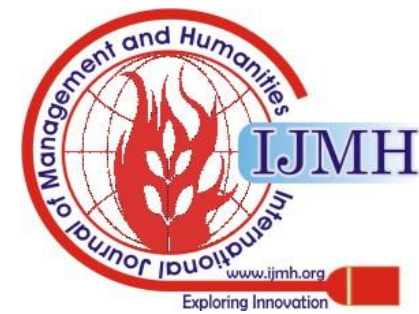


1) The concept of the problem of the formation of a civic culture needs to be developed continuously in stages: civic identity, multiculturalism and cultural expression; ethnic, racial and social tolerance; readiness for civic participation in public and state structures; ability to democratic civic leadership.

2) Each stage has inherent components of civic culture: institutional socio-political experience, civic legal consciousness and conventional and non-conventional behavior in an active and passive form.

3) The effectiveness of work on the formation of a civic culture in the face of changing unstable socio-political conditions, risks and challenges of the time is possible in the mode of continuing education throughout life. Most often in secondary school this task is carried out by educational disciplines: civic education, the basics of law and social studies.

4) Unfortunately, in conditions of continuing education in the field of civic culture, the results are scattered under the influence of social reality.

5) Therefore, in higher professional education, it is necessary to develop the formation of a civic culture in the classroom curriculum and non-audit public options.

This study combines cooperation with the Committee of the Council of the Federation of Russia on constitutional legislation, legal and judicial issues, development of civil society, the Interregional Association for Civic Education, the Center for the Implementation of State Educational Policy and Information Technologies, the Public Council for Civic Education of the Perm Territory.

Further scientific discussion is needed on how we can promote our democracy: do we need more or less direct participation of citizens? Are there any short-term fixes for what seems like a long-term problem?

\section{CONCLUSION}

Today, in the context of the transformation of political culture in Russia, the role and importance of political education and socialization is growing, the result of which should become a new political culture of a civic type.

The practical significance lies in the hope of the author that the results of the study and the proposals put forward can contribute to the adoption of mature decisions of the Ministry of Education of the Russian Federation and the Ministry of Science and Higher Education of the Russian Federation, the dissemination of experience is planned in the system of national general, special and higher education at the national and local levels.

The recommendations developed will find application in the development and implementation of the Russian National Policy Strategy with the provision of experience in relevant state and public structures of Russia (Council under the President of the Russian Federation on interethnic relations, Council of the Assembly of Peoples of Russia, Public Chamber of the Russian Federation, Center for the Implementation of State Educational Policy). and information technology", etc.).

The study does not exhaust all issues related to the formation of civic culture and implies further development.

\section{REFERENCES}

1. G. Almond, S. Verba, The Civic Culture. Political attitudes and democracy in five nations, 1963. Princeton, P. 5, 8, 19.

2. L. N. Shlyk, Political culture as a socio cultural phenomenon Chelyabinsk. 2004 P. 187.

3. Dolinina, I. G. Formation of the political culture of students. AST Moscow - Perm, $2008.260 \mathrm{p}$

4. Dolinina, I. G. The formation of political culture: the experience of methodological design. Perm, 2011. 366 p.

5. I. G. Dolinina, O. I. Korchagina, "Forming the civic participation and culture interethnic interaction of students"'. International Journal of Recent Technology and Engineering 2019 Vol. 8, Issue -3, September ISSN 2277-3878, IF: 5,92 Available: https://www.ijrte.org/wp-content/uploads/papers/v8i3/C5941098319.p $\underline{\mathrm{df}}$

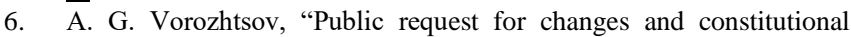
reform in Russia" Power 2019 No. 5. pp. 89-92.

7. V. D. Zorkin, "The letter and spirit of the Constitution". Russian newspaper. 2018. October $9^{\text {th }}$.

8. Twenty-five years of social transformations in the assessments and judgments of Russians (edited by M. K. Gorshkov, V. V. Pastukhov). 2018. M.: The World. 384 p.

9. Constitution of the Russian Federation of December 12, 1993/ Collection of the legislation of the Russian Federation. 01/26/2009. No. 4. Art. 445. 2019'05 Power, p. 187.

10. E. A. Grishina, (1997) Dynamics of changes in the political orientations of youth. 1995-1997. Youth 1997: hopes and disappointments. Book 1. M.

11. E. A. Grishina, Youth civic identity concept. Sociological collection. Issue 6. M . Socium, 2000.

12. E. A. Grishina, Russian youth: problems of civic identity. M., 1999.

13. I. G. Dolinina, V. N. Alexeev, Interactive and online methods of forming civic competence of students. Advances in Educational Technologies: Proceedings of the 2014 International Conference on Education and Modern Educational Technologies (EMET 2014), Santorini Island, Greece, July 18-20, 2014. - Santorini Island : [s. n.], 2014. pp. 76-83.

14. Federal Law "About Education in the Russian Federation" N 273-FL. 2012.

15. I. G. Dolinina, E. A. Shakirova, Legal education - a purposeful process of formation of legal culture of preparing students for public participation. Advances in Educational Technologies: Proceedings of the 2014 International Conference on Education and Modern Educational Technologies (EMET 2014), Santorini Island, Greece, July 18-20, 2014. - Santorini Island : [s. n.], 2014. pp. 186-201.

16. I. G. Dolinina, "Civic culture at pedagogical activity in contemporary Russia”. Life Science Journal 2014;11(5), Available: http://www.lifesciencesite.com

17. I. G. Dolinina, "Preparation of Students for Citizen's Identity". International Journal of Learning and Teaching Vol. 5, No.1, March 2019, pp. 83-93. doi: 10.18178/ijlt.5.1.88-93 Available: http://www.ijlt.org/index.php?m=content\&c=index\&a=lists\&catid=13 $\underline{5}$

\section{AUTHORS PROFILE}

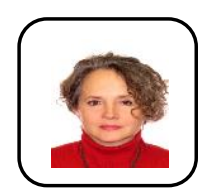

Dr. I. Dolinina conducts continued research in many regions in educational and social institutions of Russia, Great Britain, Switzerland and the USA.

By the beginning of 2020, the Russian Science Citation Index shows 99 articles and the Hirsch Index 10. Key scientific achievements and public recognition John Locke Medal of the European Scientific and Industrial Consortium for internationally recognized contribution to pedagogical science and education. (www.euscience.info).Implementation of projects supported by grants:

Leader of the project "Formation of the political culture of students" with the support of the grant of the Russian Humanitarian Science Foundation No. 06-06-82601 a / $\mathrm{u}$; Head of the project "Legal education and the formation of civic competence of youth of the Perm Territory" with the support of the grant of the Russian Humanitarian Science Foundation.

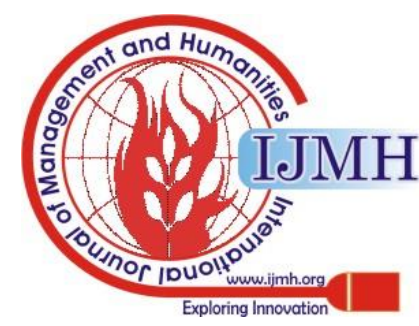

